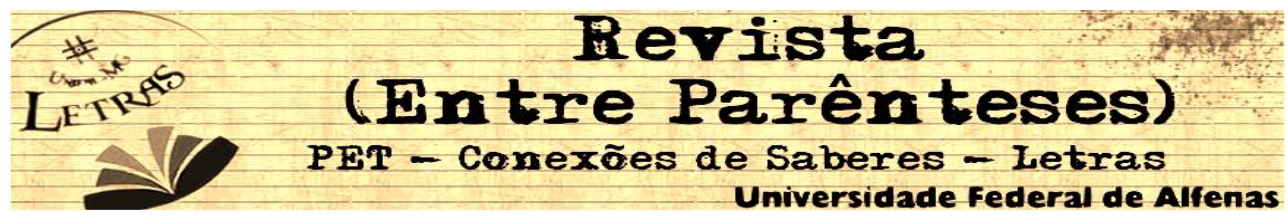

\title{
CALDERÓN E A ALEGORIA DA CAVERNA: ASPECTOS PLATÔNICOS EM 'LA VIDA ES SUEÑO'
}

\author{
Laisa Alves de Vasconcelos ${ }^{1}$ \\ Universidade Federal de Alfenas (UNIFAL-MG) \\ vasconcelos.laisa@hotmail.com \\ Kátia Aparecida da Silva Oliveira ${ }^{2}$ \\ Universidade Federal de Alfenas (UNIFAL-MG) \\ katiaoli@gmail.com
}

\begin{abstract}
Resumo: Ao lermos La vida es Sueño, de Pedro Calderón de la Barca, podemos notar alguns aspectos da Alegoria da Caverna (A República, Livro VII) entrelaçados à história de Segismundo, sua personagem central. Esses aspectos aparecem especialmente em três momentos da peça de Calderón de la Barca: quando, no primeiro ato, a personagem Segismundo está presa em uma torre; no segundo ato, quando Basílio, seu pai, o liberta momentaneamente e, por fim, quando Segismundo alcança liberdade completa. Porém, ao mesmo tempo em que Calderón utiliza a Alegoria de Platão, ele a modifica, criando outro sentido para a mesma. Esse trabalho tem como objetivo apontar esses distanciamentos e aproximações, analisando a maneira como o escritor espanhol modifica o sentido da Alegoria de Platão a fim de aproximá-la do pensamento de sua época.
\end{abstract}

Palavras-chave: La Vida es Sueño; Alegoria da Caverna; Calderón de La Barca; Platão.

Resumen:Cuando leemos La Vida es Sueño, de Pedro Calderón de La Barca, podemos percibir algunos aspectos de la Alegoría de la Caverna (La República, Libro VII) relacionados a la historia de Segismundo, su personaje central. Estos aspectos aparecen especialmente en tres momentos de la pieza de Calderón de la Barca: cuando, en el primer acto, el personaje Segismundo está preso en una torre; en el segundo acto, cuando Basílio, su padre, lo liberta momentaneamente, y por ende, cuando Segismundo alcanza la libertad completa. Sin embargo, al mismo tiempo que Calderón utiliza la Alegoría de Platón, él la modifica, creando un otro sentido para la misma. Este trabajo tiene como objetivo señalar estos distanciamientos y aproximaciones, analizando la manera como el escritor español cambia el sentido de la Alegoría de Platón, con vistas a aproximarla al pensamiento de su época.

Palabras-clave: La Vida es Sueño; Alegoría de la Caverna, Calderón de la Barca; Platón.

\footnotetext{
${ }_{1}^{1}$ Aluna de graduação do Curso de Letras da UNIFAL-MG.

2 Professora de língua e literatura espanhola da UNIFAL-MG, doutoranda em Letras pela UNESP/Assis.
}

$1 \frac{\text { Revista (Entre Parênteses) }}{$\cline { 2 - 2 }}




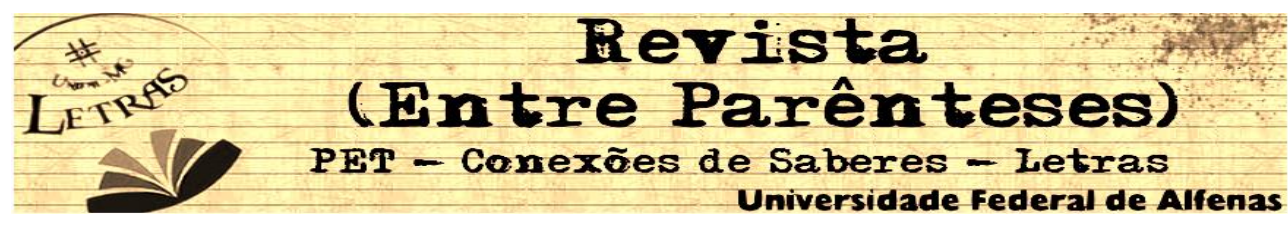

Palabras clave: La Vida es Sueño; Alegoría de la Caverna; Calderón de La Barca; Platão.

\section{Introdução}

"La vida es sueño", publicada em 1636, é uma das obras dramáticas mais conhecidas do escritor espanhol Pedro Calderón de la Barca $(1600$ - 1681) e do siglo de oro espanhol. Nessa obra, considerada parte do ciclo filosófico das obras de Calderón (VALBUENA PRAT, 1930, p.218), é apresentada a história de Segismundo, um príncipe que - graças a uma profecia astrológica - é encarcerado desde o seu nascimento. Esse príncipe que, ao longo da história, é retirado de sua prisão para ser testado, ou melhor, para que soubessem se a profecia estava correta ou não, acaba falhando como monarca - motivo pelo qual é novamente encarcerado. No final da obra, a história de Segismundo chega ao conhecimento do povo, que o liberta e the restitui o poder. Tendo aprendido com sua experiência anterior, o príncipe tem a oportunidade de transformar-se em um monarca nobre e valoroso.

Conhecendo a temática de "La vida es sueño" e desenvolvendo uma leitura mais atenta da obra é possível perceber uma interessante semelhança entre 0 argumento que a obra apresenta e a conhecida alegoria da caverna, apresentada por Platão na República (livro VII). O texto do escritor espanhol parece dialogar e, de certa forma, transformar a alegoria criada por Platão, adaptando-a a realidade vivenciada pelos espanhóis no século XVII e ao pensamento barroco e contrarreformista vigente.

Nesse sentido, o objetivo desse projeto é desenvolver um estudo crítico da obra de Calderón de la Barca considerando a sua 


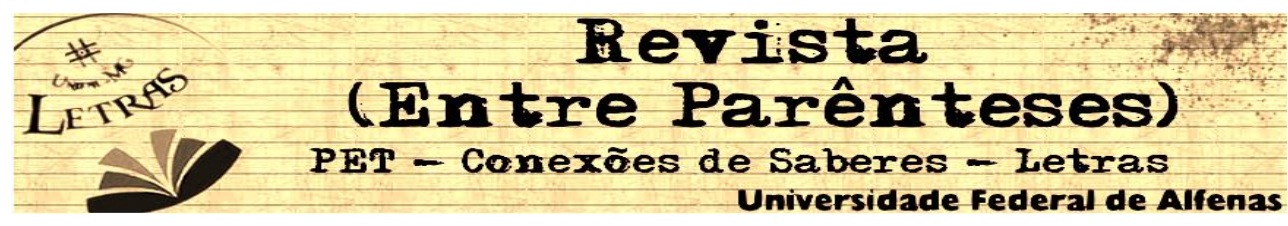

relação com a alegoria da caverna e analisando a forma como essa alegoria é retomada e transformada pelo autor espanhol.

Antes de tudo, para podermos compreender melhor a obra La vida es sueño ${ }^{3}$, de Pedro Calderón de la Barca, é importante considerarmos brevemente a época em que foi escrita. Naquele momento, A literatura espanhola passava pelo o que alguns estudiosos, entre eles Mario González (2010, p.61), chamam de "Século de ouro" (Siglo de Oro).

A Espanha viveu o seu apogeu cultural no período que abrangeu especialmente o Renascimento no século XVI e o Barroco no século XVII. Nesse período a produção literária espanhola ganhou notoriedade e teve em destaque alguns autores importantes, como Miguel de Cervantes, Francisco de Quevedo, Tirso de Molina, Góngora, Lope de Vega, Calderón de La Barca, entre outros.

Mário González (2010, p. 62) comenta que "É evidente que o século XVI significa, antes de tudo, a definitiva penetração da sensibilidade renascentista na literatura espanhola", ou seja, podese inferir que ao longo desse século percebeu-se a influência do Renascimento em diferentes obras literárias.

O Renascimento nas artes se caracterizou, entre outros aspectos, por uma retomada dos clássicos, pela busca do equilíbrio e do belo. Hauser (1996, p. 16), porém, afirma que "os períodos da arte clássica caracterizados pela absoluta disciplina da forma, pela completa penetração da realidade, pelos princípios da ordem e pela total sujeição da auto expressão à harmonia e beleza, são de duração relativamente breve".

Para o autor, períodos artísticos como o Renascimento - que recuperam os clássicos - têm pouca duração, pois uma arte que

\footnotetext{
${ }^{3}$ Será utilizada nesse trabalho a seguinte edição da obra: CALDERÓN DE LA BARCA, Pedro. La vida es Sueño. Madrid: Editorial Espasa Calpe, 2000.
} 


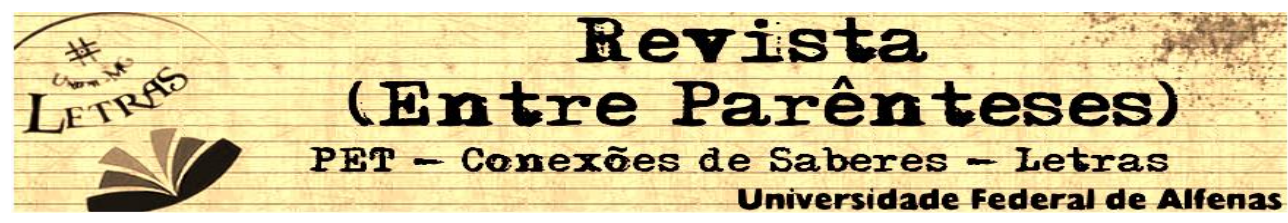

busca perfeição das formas pode parecer falsa (HAUSER, 1996. p. 17). Nesse sentido, Hauser aponta, ao falar sobre essa duração breve, para uma crise, ou melhor, para uma transição que a Renascença enfrentaria:

O que significamos por crise da Renascença aparece mais claramente na crise do humanismo, no questionamento da vaidade de toda a síntese filosófica que, tomando posição no homem e em suas necessidades espirituais, tentou reconciliar o legado da Antiguidade com o da Idade Média e reconciliar ambos com o presente. (HAUSER, 1996, p. 18)

Tal crise, fundamentada na própria crise do homem que tenta conciliar os ideais renascentistas à visão de mundo religiosa e pessoal, gerou o que conhecemos hoje como o maneirismo e o barroco. Concentrar-nos-emos mais adiante no Barroco por ser a este movimento que consideramos pertencer a obra de Calderón de la Barca que é objeto desse estudo.

Pensando no caso da Espanha, pode-se dizer que além do fato de que o Renascimento ocupou um período breve de sua história, que não houve uma adesão por completo a esse pensamento.

Como parte de uma evolução do Renascimento, o Barroco se desenvolveu buscando atentar para as necessidades espirituais do homem e aliando-se a uma ideologia religiosa específica da época: a católica contrarreformista.

Sobre o Barroco, Hatzfeld (2002) afirma:

O Barroco implica a tendência pela qual as novas ideologias religiosas e políticas da Contra-reforma e do absolutismo selecionaram algumas das formas maneiristas e as preencheram com novo conteúdo. Ao mesmo tempo, em contradição com o caráter mais privado do Maneirismo, o Barroco assumiu uma função pública e representativa. (HATZFELD, 2002, p. 146) 
O Barroco, como diz Hatzfeld, assume uma função pública, de maneira que seria possível afirmar que ele acaba por tornar-se quase um "instrumento" da Contra- Reforma, no sentido de que, principalmente na literatura, propagava um pensamento muito afinado ao religioso e atingia um público numeroso.

González (2010) fala sobre essa questão, especificamente na Espanha:

Na Espanha, é peculiarmente intenso o atrelamento da arte e da literatura barrocas à cosmovisão católica contrarreformista que, por sua vez, é a base ideológica que sustenta o sistema político espanhol na evolução do modelo implantado a partir dos Reis Católicos. (GONZÁLEZ, 2010, p. 388)

Pode-se pensar, assim, que o Barroco espanhol mostra-se intimamente ligado à visão católica contrarreformista vigente na Espanha do período. Esta relação íntima da arte com uma visão religiosa seguramente pode ser identificada nas obras literárias consideradas barrocas.

No período em que o barroco se desenvolvia na Espanha, viveu Calderón de La Barca. Sua vida por várias vezes tem sido chamada de "biografia do silêncio" (CANAVAGIO, 1995, p. 198) porque são de nosso conhecimento apenas alguns acontecimentos pessoais. Sabe-se que Calderón procedia de uma família nobre, porém não tão influente, sabe-se também que estudou nas Universidades de Alcalá e Salamanca, que foi soldado durante a guerra de Cataluña e que ao voltar da guerra, ingressou no sacerdócio e se tornou um protegido da coroa. A partir de então, ele passou a escrever autos e peças para a realeza.

Como Calderón havia se tornado protegido dos monarcas e havia uma relação muito próxima entre Igreja e Estado, alguns de seus autos e peças têm como temática a religiosidade e 


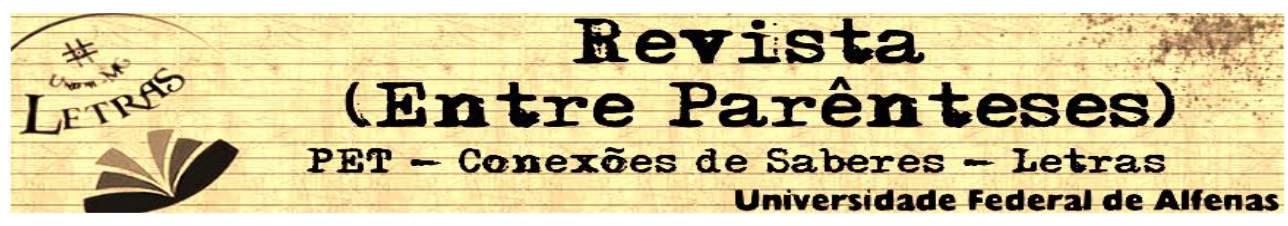

principalmente o fato de "depender o destino do homem de sua adesão aos preceitos morais, aos dogmas e aos ritos da lgreja Católica, que encarava a priorização dos valores espirituais" (GONZÁLEZ, 2010, p.73).

A obra La Vida es Sueño (1636), é uma peça na qual pode se notar uma relação entre a arte, o clero e a monarquia. A peça conta a história de um rei, Basílio, que ao ouvir um presságio de que seu filho, no futuro, assumiria o poder e seria um governante tirano, opta por trancafiá-lo em uma torre, longe de qualquer convívio social. Apenas Clotaldo, seu servo, tem permissão para ver Segismundo o príncipe cativo - e ensinar-Ihe coisas básicas como a leitura, a escrita, a religião, etc.

$\mathrm{Na}$ peça, Segismundo permanece prisioneiro por anos sem sequer imaginar suas verdadeiras origens até que, um dia, Basílio decide colocar a profecia à prova e o leva ao palácio, revelando-Ihe sua verdadeira história. Por ser exposto tão bruscamente à verdade, Segismundo acaba agindo de maneira tirânica e é mandado novamente à prisão. De volta à cela, o príncipe acredita que tudo aquilo que viveu não passou de um simples sonho. Porém, torna-se de conhecimento o fato de que havia um príncipe vivendo aprisionado. Isso fez com que o povo se unisse para libertá-lo, restituindo-Ihe seus direitos como príncipe herdeiro. Completamente mudado após refletir sobre seu "sonho", Segismundo perdoa o pai e Clotaldo, pune o oficial que cedeu à rebelião do povo e torna-se um rei justo e admirado pelos súditos.

Como escritor do barroco, Calderón recupera os clássicos em sua obra. Nesse caso, podemos perceber uma relação intertextual de La vida es Sueño com a "Alegoria da caverna", de Platão ( A República, livro VII). Observar-se-á adiante que a Alegoria apresentada por Platão exemplifica como realidade e ilusão podem ser relativas e é revisitada e adaptada por Calderón em sua época. 


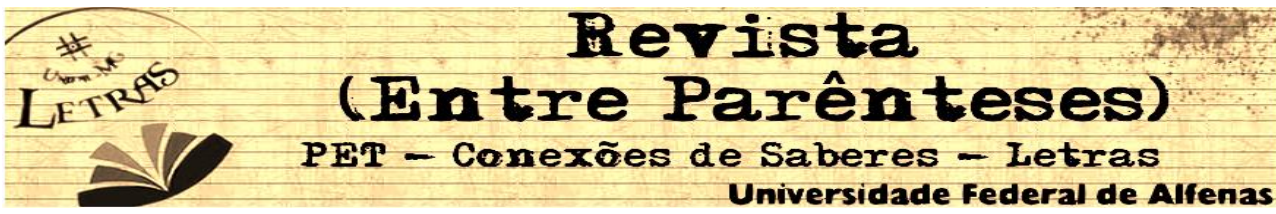

\section{A Alegoria da Caverna em La vida es sueño}

Neste trabalho, ao tratar da narrativa de Platão, optamos por utilizar o termo "alegoria" e não "mito", como alguns estudiosos costumam usar, uma vez que Turchi (2007, p. 18) aponta que "A alegoria significa diretamente e sua razão de existência é transmitir um sentido. O símbolo é uma representação, por isso produz um efeito, enquanto a alegoria, uma designação, um sentido que se transmite e que se aprende". Ou seja, a alegoria é um modo direto de exemplificar uma situação com o objetivo de transmitir um efeito a partir de tal exemplo, tal qual acontece na narrativa de Platão.

No livro A República ${ }^{4}$, Platão nos apresenta uma alegoria criada por Sócrates para exemplificar como realidade e ilusão podem ser relativas. Nessa alegoria, Sócrates discorre sobre pessoas que vivem em uma caverna e, em meio à escuridão, apenas avistam sombras do mundo exterior refletidas ao seu fundo e, como não conhecem nada além das sombras, vivem como se elas fossem seres reais. Entretanto, uma dessas pessoas consegue sair da caverna. Por não estar acostumada com a claridade, tem certa dificuldade para enxergar inicialmente, mas - após certo período de adaptação - consegue enxergar o mundo exterior e perceber que aquilo que antes tomava como verdade, não passava de uma mera ilusão. Ao tentar retornar à caverna, essa pessoa precisará novamente passar por uma adaptação para que possa voltar a enxergar em meio à escuridão. Porém, por ter se desacostumado a enxergar na escuridão, não conseguirá ver as sombras com a aptidão anterior e pode ser rejeitada por seus companheiros.

\footnotetext{
${ }^{4}$ Para este trabalho, utilizaremos a edição: PLATÃO. A República. Trad. Eduardo Menezes. São Paulo: Hemus, 1991.
} 


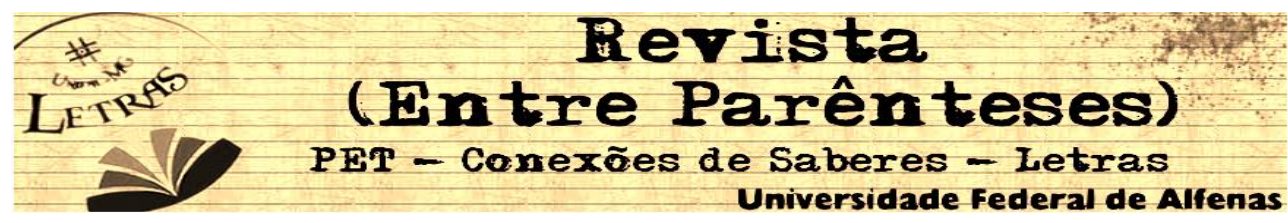

A respeito dessa alegoria, Santos e Silva (2010) explicam:

\begin{abstract}
A alegoria de Platão aponta para como a aparência pode ser tomada como o verdadeiro e para a forma como o conceito daquilo que é real se encontra dotado de complexidade, já que um dado objeto será interpretado como sendo real a partir da perspectiva pela qual é concebido. (2010, p. 05)
\end{abstract}

Ou seja, Platão chamava a atenção para como a ilusão pode ser confundida com a realidade quando não há conhecimento.

Ao analisarmos essa alegoria e seu propósito pedagógico, podemos notar uma intertextualidade entre o clássico filosófico e a obra espanhola La Vida es Sueño. Segismundo, protagonista da peça, também está condicionado à vida em uma "caverna" - a prisão em que vive. Porém, diferente da alegoria de Platão, ele não só parece ter noção das coisas existentes fora da torre em que vive, mas também de que sua própria existência, naquelas condições, não fazia sentido.

Logo em sua segunda fala na peça Segismundo deixa-nos claro que sua condição é diferente da dos demais seres e que, de alguma maneira, ele sabe que está sofrendo uma punição, embora não saiba o que fez para merecê-la:

\title{
SEGISMUNDO:
}

¡Ay mísero de mí! ¡Y ay infelice!

Apurar, cielos, pretendo

ya que me tratáis así,

qué delito cometí

contra vosotros naciendo;

aunque si nací, ya entiendo

qué delito he cometido.

Bastante causa ha tenido

vuestra justicia y rigor;

pues el delito mayor

del hombre es haber nacido.

Sólo quisiera saber,

para apurar mis desvelos

(dejando a una parte, cielos,

el delito de nacer), 


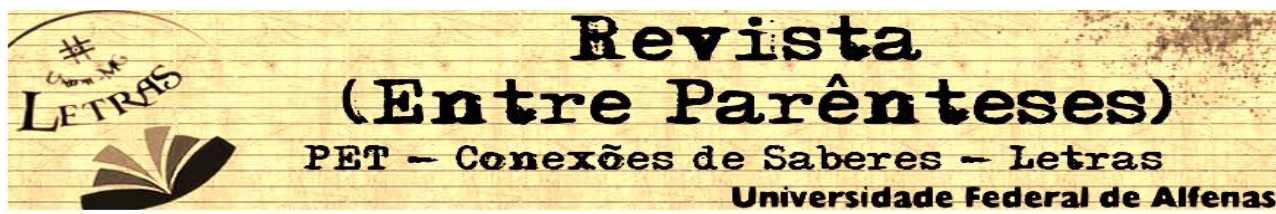

qué más os pude ofender, para castigarme más.

¿No nacieron los demás?

Pues si los demás nacieron, ¿qué privilegios tuvieron que yo no gocé jamás?

(CALDERÓN DE LA BARCA,2000, p. 86)

Segismundo está ciente de sua situação desfavorecida, diferente do que acontece com os homens da alegoria de Platão, entretanto, não sabe o motivo de seu sofrimento.

Nesse ponto há um distanciamento entre a peça de Calderón e a alegoria de Platão. A personagem Segismundo demonstra ter alguns "raios de luz" dentro de sua caverna - certo nível de conhecimento em relação ao mundo. $E$ de onde viriam esses raios de luz? Como já citado, Segismundo foi ensinado por Clotaldo, a única pessoa com quem tinha contato. Nesse contexto, poderíamos chegar a dizer que Clotaldo é aquele que viu o mundo externo e voltou para contar aos outros (no caso, Segismundo). Contudo, essa seria uma informação equivocada, uma vez que Clotaldo não saiu da 'escuridão' e não estava na torre com o objetivo de revelar que aquela era uma vida ilusória. Ao contrário: estava ali aos serviços do rei Basílio e dava a Segismundo apenas as informações que the eram permitidas.

Podemos pensar que esse distanciamento tem seu objetivo. Lembrando o atrelamento da arte barroca à cosmovisão católica contrarreformista, citada por González, essa ênfase que a personagem dá em questionar o que havia feito de errado, se estava sendo vítima de algum castigo divino, poderia remeter os espectadores da peça a um pensamento mais voltado à questão de transcendência: mesmo sabendo que estava sendo injustiçado, ele submetia-se a uma "vontade divina" que ele imaginava ser responsável pela sua situação, e, mais tarde, ao descobrir a 


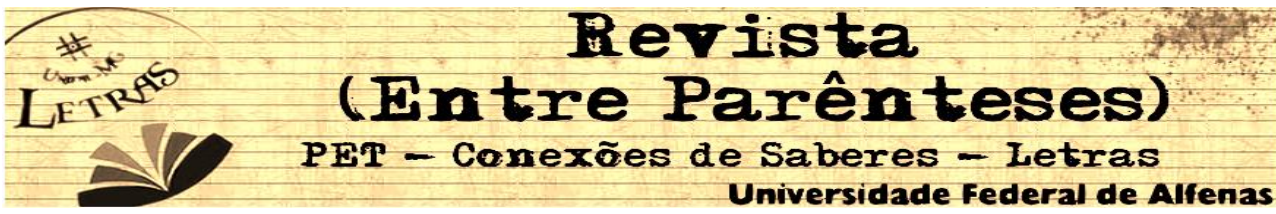

verdade, a personagem foi capaz de perdoar quem o fez sofrer essa injustiça.

Sobre essa visão barroca do divino Hatzfeld (2002, p. 151) diz: "No Barroco, pois, o amor divino significa a libertação triunfante de todas as travas terrestres, a liberdade que só é possível conseguir através deste amor". Com o objetivo ideológico contrarreformista em mente, Calderón leva seu público a ver a importância de transcender como ser humano: aproximar-se do amor divino, pois essa era a real liberdade que uma pessoa poderia ter.

Quando, no segundo ato da peça, o rei Basílio coloca as predições que o levaram a encarcerar o próprio filho à prova e leva Segismundo ao palácio, temos novamente uma relação que alude à alegoria de Platão. Nesse momento é como se Segismundo tivesse saído da caverna e se deparado com a claridade do mundo externo. Assim como na alegoria, seria necessária uma adaptação que, em La Vida es Sueño, não ocorre. Ao descobrir que era um príncipe e que seu próprio pai era o responsável por sua vida em uma prisão, Segismundo não consegue lidar com a situação, agindo de maneira hostil:

SEGISMUNDO:(Aparte)

Clotaldo es; pues ¿cómo así quien en prisión me maltrata con tal respeto me trata?

¿Qué es lo que pasa por mí?

CLOTALDO:

Con la grande confusión que el nuevo estado te da, rnil dudas padecerá el discurso y la razón. Pero ya librarte quiero de todas, si puede ser, porque has, señor, de saber que eres príncipe heredero de Polonia. Si has estado retirado y escondido, por obedecer ha sido 


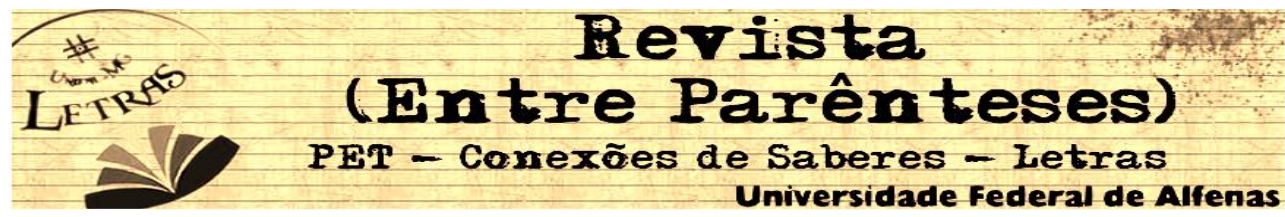

\begin{abstract}
a la inclemencia del hado, que mil tragedias consiente a este imperio, cuando en él el soberano laurel corone tu augusta frente. Mas fiando a tu atención que vencerás las estrellas, porque es posible vencellas a un magnánimo varón, a palacio te han traído de la torre en que vivías, mientras al sueño tenías el espíritu rendido.

Tu padre, el Rey mi señor, vendrá a verte, y dél sabrás, Segismundo, lo demás.

SEGISMUNDO:

Pues vil, infame y traidor, ¿qué tengo más que saber, tal traición, que me ocultaste después de saber quién soy, para mostrar desde hoy mi soberbia y mi poder? ¿Cómo a tu patria le has hecho a mí, pues que me negaste, contra razón y derecho, este estado?
\end{abstract}

(CALDERÓN DE LA BARCA,2000 p. 126)

Observa-se que, ao se ver livre, Segismundo não consegue controlar sua ira perante a verdade que the é exposta e age como um tirano.

A reação de Segismundo a essa nova realidade se dá devido ao pouco tempo que ele tem para se adaptar e à maneira que essa realidade lhe é apresentada. Assim como o homem da alegoria, que, ao sair da caverna, necessita de um tempo para poder adaptar-se à claridade do mundo exterior, Segismundo precisaria de certo tempo para poder adaptar-se a sua nova realidade e para poder entender a verdade de sua história. A personagem, assim como na alegoria de Platão, chega a ter conhecimento da verdade, todavia, não tem o tempo necessário para se adaptar a esse "mundo exterior" e, após ver a ira do filho, o rei Basílio - pensando que as profecias que conhecia eram verdadeiras - manda que o aprisionem novamente. 


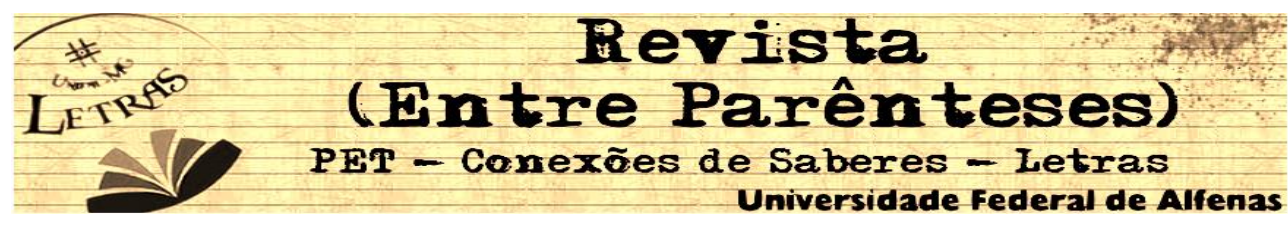

Novamente preso na torre, Segismundo pensa que tudo não passou de um mero sonho. Mas mesmo acreditando ter se tratado apenas de uma ilusão, o príncipe tem outra postura em relação ao comportamento hostil que havia adotado no suposto sonho, assim como uma pessoa que saísse da caverna a veria de modo diferente caso voltasse a ela. Não obstante, há um novo distanciamento entre a peça de Calderón e a Alegoria de Platão: na alegoria, haveria uma nova transição da luz para a escuridão e essa volta poderia ser um meio de alertar os outros que ali estivessem. Segismundo não havia conseguido se adaptar à vida fora de sua prisão, logo, ele ainda não havia se adaptado à 'claridade' do mundo exterior. Somente quando ele volta à prisão, acreditando que tudo não havia passado de um sonho, consegue tirar conclusões sobre as atitudes por ele tomadas no "sonho". Porém, o fato de voltar à sua vida de prisioneiro e acreditar que o que havia vivido era apenas um sonho, faz com que ele, de certa maneira, volte à 'escuridão'. Segismundo parece ser uma personagem que está no "meio do caminho" com relação à alegoria de Platão: nem há uma completa adaptação à luz, num primeiro momento, e nem uma completa readaptação à escuridão.

Após se tornar de conhecimento público a existência de um príncipe encarcerado, a população decide libertá-lo para que possa assumir o lugar que the pertence por direito. É nesse momento que podemos afirmar que Segismundo sai definitivamente da caverna e se adapta à nova realidade.

Todavia, essa adaptação aconteceu dentro da torre, enquanto ainda pensava que tudo o que havia vivido era um sonho. Mesmo de volta à 'escuridão', Segismundo concluiu que as atitudes tomadas no sonho que teve não eram dignas de um sábio governante. Ele precisava de tempo para pensar nos acontecimentos que vivenciou, ainda que pensasse que tudo não passou de um sonho e, a partir dessa reflexão, optou por transcender, agindo de uma maneira Revista (Entre Parênteses) 


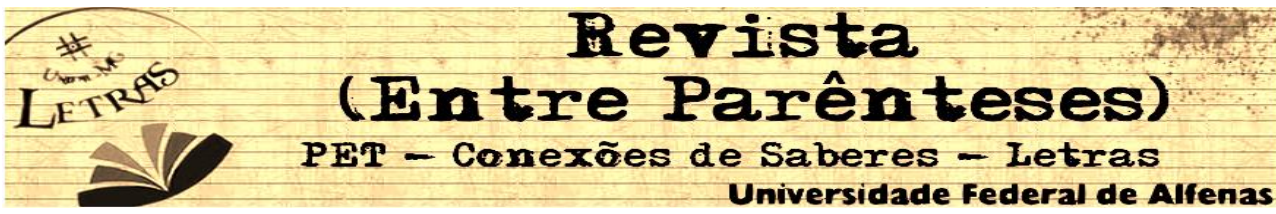

melhor para sua vida futura, pensamento esse que ia de acordo com a ideologia contrarreformista.

Após ser coroado, o príncipe dá o perdão a Clotaldo e a seu pai Basílio. Porém Segismundo pune um dos soldados que o libertaram:

\author{
SOLDADO 1: \\ Si así a quien no te ha servido \\ honras, ¿a mí, que fui causa \\ del alboroto del reino, \\ y de la torre en que estabas \\ te saqué, qué me darás? \\ SEGISMUNDO: \\ La torre; y porque no salgas \\ della nunca hasta morir, \\ has de estar allí con guardas; \\ que el traidor no es menester \\ siendo la traición pasada.
}

(CALDERÓN DE LA BARCA, 2000, p. 194)

Esse desfecho mostraria à população que não é correto se rebelar contra a monarquia, pois isso teria um preço: no caso do soldado, a vida em uma prisão. Era importante ser uma boa pessoa, e ainda mais importante era respeitar a hierarquia e o Estado. Novamente, a influência da época e do propósito educacional que a obra de Calderón apresenta levam os espectadores à questão da transcendência do ser humano, em sempre buscar tornar-se uma pessoa melhor, além de pregar a obediência aos seus governantes.

Assim, obedecer à monarquia é também um dos elementos que se identifica na obra. Os governantes são retratados aqui como seres sábios e capazes de decidir o melhor destino de seus súditos. Obedecer ao Estado, nesse caso, é seguir normas que podem contribuir para a transcendência individual.

Podemos notar, no decorrer da peça, a evolução de Segismundo como ser humano: de uma pessoa presa, afastada do mundo, a uma pessoa capaz de perdoar, sábia e justa. Tal como o 


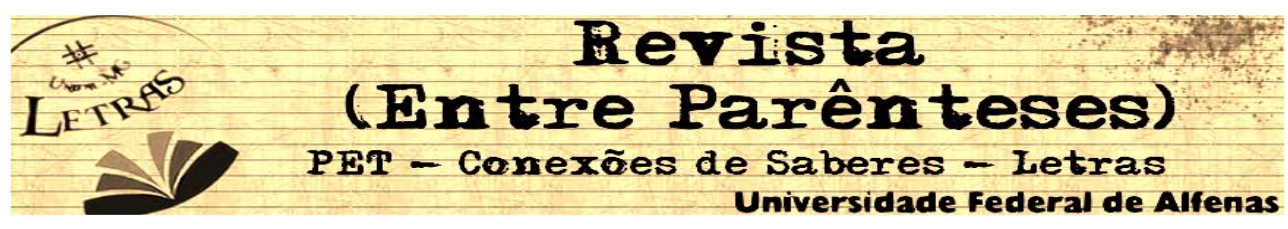

homem na Alegoria de Platão, Segismundo estava condicionado a uma vida presa a ilusões. Ao alcançar o conhecimento do mundo exterior, ele passa por uma transformação individual e transcendente. Nesse sentido podemos observar a influência da ideologia religiosa da época, utilizada por Calderón para fazer com que sua personagem se tornasse um exemplo de transcendência do ser humano.

\section{Considerações finais}

Ao longo de La vida es sueño, Calderón de la Barca utiliza uma obra da filosofia grega para apresentar o público a temática da transcendência. Porém, a maneira como ele modifica a alegoria da caverna ao utilizá-la em sua peça, acaba por modificar também seu significado final.

Enquanto Platão usava da alegoria para mostrar o quão libertadora pode ser a verdade- ou o conhecimento - em comparação a viver uma vida ilusória, que limita as pessoas como se estivessem 'presas em uma caverna', Calderón modifica-a, usando do pensamento contrarreformista e mostrando ao seu público que o ser humano precisa transcender, alcançar o amor divino, pois somente isso irá libertá-lo dessa prisão, dessa 'escuridão'.

Havia por trás dessa relação intertextual entre a peça calderoniana e a alegoria de Platão um propósito pedagógico. Como já mencionado, a arte barroca espanhola estava atrelada a uma visão religiosa, mais especificamente a uma visão católica do mundo, e essa visão, por sua vez, contribuía para a manutenção de um sistema político. Ao mostrar à população, por meio se sua peça, que o modo correto de agir era procurando sempre alcançar essa 


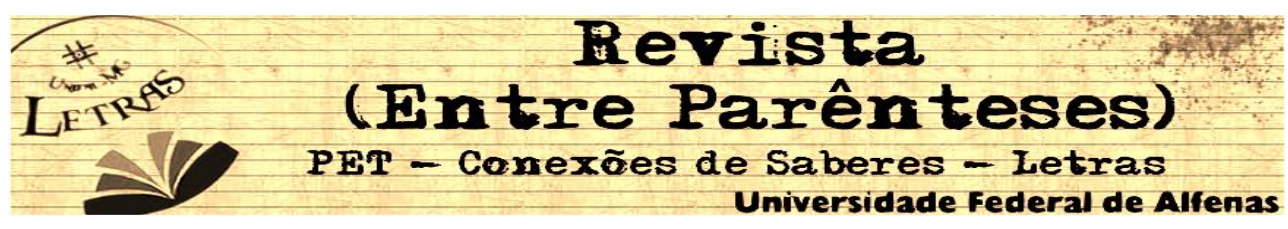

transcendência, agir como um bom cristão, Calderón também mostrava que o bom cristão obedecia ao Rei.

Nesse trabalho, pudemos perceber a relação intertextual entre as obras dos dois autores e também as mudanças feitas por Calderón no decorrer de sua obra para utilizar esse grande clássico da filosofia, visando alcançar os objetivos que the haviam sido incumbidos. Calderón, ao entrelaçar a Alegoria da caverna ao seu texto, não só procurou retornar a um clássico, mas adaptá-lo à sua época e ao valor educacional que sua peça poderia alcançar, fazendo assim com que uma obra filosófica servisse aos propósitos da época do Rei e da Igreja.

\section{Referências bibliográficas}

CALDERÓN DE LA BARCA, P. La vida es Sueño. Madrid: Editorial Espasa Calpe, 2000.

CANAVAGGIO, J. Historia de la literatura española. Tomo III. El siglo XVII. Traducción de Juana Bignozzi. Barcelona, Ariel, 1995.

GONZÁLEZ, M. M. Leituras de Literatura Espanhola (da Idade Média ao século XVII). São Paulo, Letraviva/Fapesp, 2010.

HATZFELD, H. Estudos sobre o Barroco.Tradução Célia Berrettini. São Paulo, Editora Perspectiva, 2002.

HAUSER, A. Maneirismo a crise da renascença e o surgimento da arte moderna. São Paulo, Editora Perspectiva,1996.

PLATÃO. A República. Trad. Eduardo Menezes. São Paulo: Hemus, 1991.

SANTOS, M. N, SILVA, J. S. "O Mito da Caverna: Diálogos entre La Vida es Sueño e O Enigma de Kaspar Hauser". In: II Seminário Nacional em Estudos da Linguagem: Diversidade, Ensino e Linguagem. UNIOESTE-

$15 \frac{\text { Revista (Entre Parênteses) }}{$\cline { 2 - 2 }}




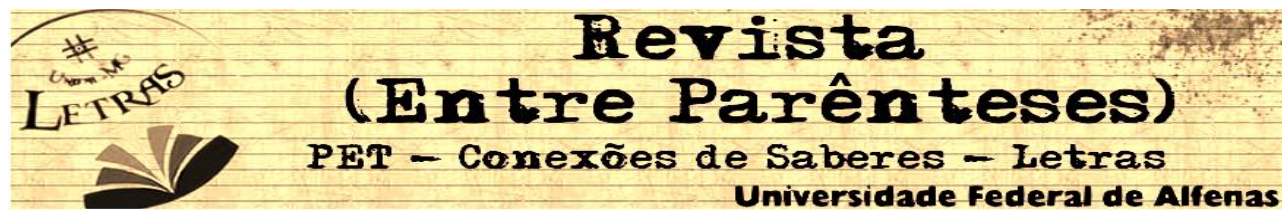

Cascavel, Paraná, 2010. Versão PDF disponível em: http://cac-

php.unioeste.br/eventos/iisnel/CD IISnell/pages/simposios/simposio\%2021 1O\%20MITO\%20DA\%20CAVERNA\%20DIALOGOS\%20ENTRE\%20LA\%2 OVIDA\%20ES\%20SUENO\%20E.pdf Acesso em: 20 maio 2012.

VALBUENA PRAT, A. Literatura Dramática Española. Barcelona: Editorial Labor, 1930. 